\title{
Uønskede graviditeter er fortsatt et stort kvinnehelseproblem
}

Hundreårsjubileet for kvinners stemmerett i Norge gir rom for ettertanke. To artikler i dette nummeret av Tidsskriftet minner oss om hvilken virkelighet de sto ovenfor, de kvinnene som ble uønsket gravide i Norge på den tiden da kvinner fikk stemmerett på linje med menn $(1,2)$. Men de minner oss også om at et uønsket svangerskap fortsatt er en katastrofe for kvinner mange steder i verden. Kvinnelig seksualitet og fruktbarhet er ikke bare viktige helseanliggender, de er også grunnleggende aspekter ved det å være menneske. Den pågående og til dels opphetede diskusjonen om utvidet reservasjonsrett viser at abortspørsmålet ikke er ukomplisert i våre dager heller. I verden i dag er det enorme ulikheter i kvinners mulighet til å overleve sine svangerskap, fødsler og aborter, både innen de enkelte land og mellom ulike land.

Kong Christian Vs norske lov av 1687 skilte ikke mellom abort og spedbarnsdrap. Det var dødsstraff for begge, og kvinnens hode skulle settes på en stake til skam og skjensel. Sex utenfor ekteskapet var straffbart. Kvinnen ble ofte straffet, mens mannen, som ikke på samme måte kunne bli avslørt av en voksende mage, stort sett gikk fri. I 1842 ble dødsstraffen erstattet med straffarbeid. Fra 1902 og helt til 1964 kunne kvinner få inntil tre års fengsel for å ta abort. Bak lovteksten skjuler det seg dramatiske livshistorier. Uttrykket «uønsket graviditet» er et svakt uttrykk for å beskrive den katastrofen det var for kvinner å komme «i uløkka». Mange risikerte liv og helse ved farlige aborter, eller de skjulte graviditeten, fødte i dølgsmål og tok livet av barnet etterpå. Alternativet var å utsette seg for sosial stigmatisering, moralsk fordømmelse og økt fattigdom ved å ha et «uekte» barn. Temaet har vært rikt utforsket av skjønnlitteraturen opp gjennom årene og viser hvilken sosial sprengkraft som lå i disse spørsmålene.

Abortlovgivningen er svært forskjellig i ulike deler av verden. I de landene som har strengest abortlovgivning, det vil si en håndfull latinamerikanske land og et par små europeiske, er enhver abort forbudt, selv den som er nødvendig for å redde en kvinnes liv. I den andre enden av skalaen finner vi Canada, som helt har fjernet abort fra straffeloven. Der vurderes inngrepet som en sak mellom en kvinne og hennes lege. Profesjonsetikken, ikke lovgivningen, legger føringene - også for senaborter. Mellom disse to ytterpunktene finnes alle sjatteringer. Noen steder er det bare tillatt med abort dersom det redder kvinnens liv, andre steder dersom det er nødvendig for å bevare hennes fysiske helse. Andre land tillater abort hvis det er fare for mental helse eller av sosioøkonomiske årsaker, mens flere land i likhet med Norge har selvbestemt abort inntil en viss svangerskapslengde. Den generelle tendensen i verden er liberalisering av abortlovgivningen, idet det er flere land som liberaliserer enn som innskrenker kriteriene for lovlig abort (3).

Vi vet etter hvert en del om konsekvenser av ulike typer abortlovgivning og om hva som skjer når loven endres. Jo strengere lovgivningen er, desto flere kvinner dør av abortkomplikasjoner. Ved liberalisering reduseres dødeligheten, iblant drastisk (3). Spedbarnsdrap fortsetter å være en desperat løsning $i$ en del land der kvinner ikke har tilgang til abort. Forekomst av abort er praktisk talt uavhengig av abortlovgivningen, den bestemmes særlig av tilgangen til prevensjon. Det er paradoksalt nok en samvariasjon mellom streng abortlovgivning og høye aborttall, og liberal lovgivning og lav fore- komst (3). Det er ikke en årsakssammenheng, men skyldes at land med streng abortlov gjerne samtidig har dårlig tilgjengelighet til prevensjon og de andre faktorene som bestemmer forekomst (3).

Lover er avgjørende for tilgang på aborttjenester og for kvinners mulighet til å overleve sine svangerskapsavbrudd. Men de virker også normgivende, altså på oppfatninger om hva som er rett og galt, hva som er moralsk og umoralsk. Mange steder der abortlovgivningen er streng, møter kvinner som avbryter sine svangerskap fordømmelse og får svært dårlig behandling. Det er ikke uvanlig at kvinnene venter unødig lenge på behandling, noe som kan gjøre at komplikasjoner som blødning eller infeksjon utvikler seg og blir mer alvorlig. Ofte får de utdatert eller farlig behandling og dårlig smertelindring (4). Uvennlig behandling, inntil utskjelling, er et betydelig problem.

Der abortlovgivningen er streng, tyr ubemidlede kvinner til farlige aborter. Behandling av abortkomplikasjoner er derfor viktig for å redusere abortrelatert sykelighet og dødelighet. Globalt samarbeides det for å bedre tilgang til og kvalitet av behandling av abortkomplikasjoner, blant annet gjennom Postabortion Care Consortium, som ble startet av den USA-baserte organisasjonen Ipas i 1993. Når helsepersonell får opplæring i slik behandling, åpnes også døren for dem til det lukkede rom som farlige, ulovlige aborter er.

I de senere årene er det blitt ettertrykkelig vist at farlige aborter er noe som alt vesentlig rammer fattige kvinner (3). Private helsetjenester utfører trygge, ulovlige aborter for dem som kan betale, mens komplikasjonene gjerne behandles på offentlige sykehus, der de utgjør en stor belastning. Selv på offentlige sykehus må kvinnene mange ganger betale skyhøye summer for behandlingen, noe som driver dem og familiene deres ut $\mathrm{i}$ enda dypere fattigdom (5). Globalt tror jeg det er mer å hente på å motarbeide denne sosiale urettferdigheten enn å diskutere seg frem til felles seksualmoral.

Berit Austveg

ba@helsetilsynet.no

Berit Austveg (f. 1948) er lege og seniorrådgiver i Statens helsetilsyn Forfatter har fylt ut ICMJE-skjemaet og oppgir ingen interessekonflikter.

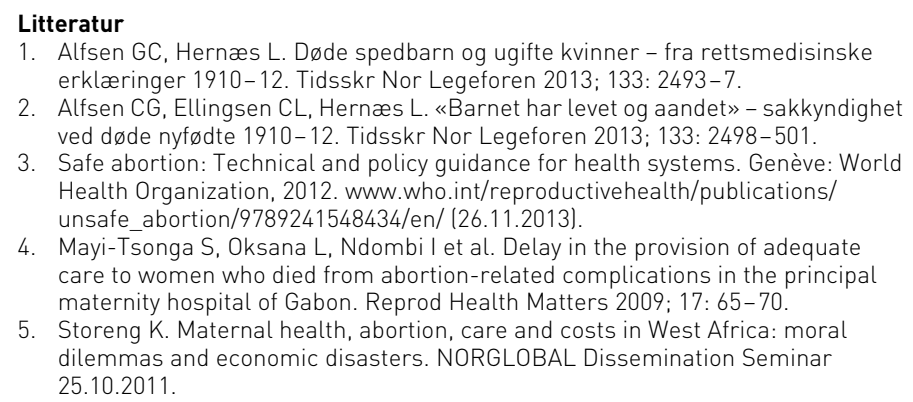

